HUNGARIAN AGRICULTURAL ENGINEERING

AND MANAGEMENT $N^{\circ} 37 / 2020$ 5-9

Published online: http://hae-journals.org/

HU ISSN 0864-7410 (Print) / HU ISSN 2415-9751(Online)

DOI: 10.17676/HAE.2020.37.27

Received: 10.11.2019. - Accepted: 20.02.2020
PERIODICAL OF THE COMITTEE OF AGRICULTURAL AND BIOSYSTEM

ENGINEERING OF

THE HUNGARIAN ACADEMY OF SCIENCES

and

SZENT ISTVÁN UNIVERSITY

Faculty of Mechanical Engineering

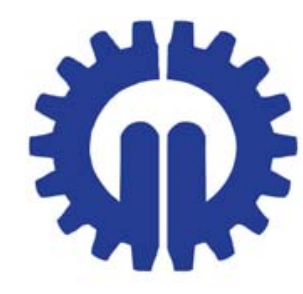

\title{
SOIL MICROBIAL PARAMETERS AND SYNERGIES BETWEEN BEAN GROWTH AND MICROBIAL INOCULUMS AS A DEPENDENCE OF FIVE SOILS WITH DIFFERENT CHARACTERISTICS
}

\author{
Author(s): \\ S. A. Pabar, D. Mónok, Zs. Kotroczó and B. Biró
}

\section{Affiliation:}

Department of Soil Science and Water Management, Szent István University, Villányi u. 29-43., Budapest, H-1118 Hungary;

\section{Email address:}

pabarattila@gmail.com

\begin{abstract}
The objective of the present study was to monitor the soil biological parameters. We used the bean as a test plant, grown in five soils with different texture and organic-matter content and estimated them (biomass production and shoot length). The seeds of the test plants were inoculated by combined strains. Results have shown that the treatments influence the counts of microorganisms. This study, therefore, was highlighting the importance of soil physical-chemical parameters, so as to result in a successful application of the biofertilizers in the different soil-plant systems.
\end{abstract}

Keywords: soil biology, Phaseolus vulgaris, MPN, biofertiliser, Hungarian soils,

\section{Introduction}

Bio-efficient solutions that can biologically deliver nutrient and crop protection in a single step can play an important role in maintaining soil use. Such soil treatments can be microbial inoculants (Dudás et al. 2017a, b; Biró 2017). Depending on the environment, microbial weights per hectare are, according to literature, between 3 and 15 tonnes, not including other participants in the soil-food web; their significance is not negligible (Kotroczó et al. 2009, Fekete et al. 2017, Béni et al. 2017).

The so-called plant growth promoting rhizobacteria (PGPR) can help plant growth in different ways (Kocsis et al. 2018) and may also synergistically strengthen each other (Kocsis and Biró 2015). PGPR functions and synergistic properties of species (Enterobacter ludwigii, Bacillus subtilis, Pseudomonas fluorescens, Kosakonia cowanii, Trichorderma harzianum, és Phanerochaeta chrysosporium) used in the experiment have been reported in several previous studies. E. ludwigii PSB is a phosphorus soluble (P-solubilizing) bacterium, biocontrol species, indole acetic acid (IAA) and iron chelating (siderophore) and increased the biomass of test plants (Shoebitz 2009, Dolkar et al. 2018, Rajnish 2018). B. subtilis is also a known biocontrol species with PSB and cellulose degrading properties (Xiaoying et al. 2015, Ahmad et al. 2019, Kim et al. 2011). P. fluorescens is also a frequent component of bacterial fertilizer due to its biocontrol, PSB, siderophore and IAA production properties (Xiaoying et al. 2015, David et al. 2018). K. cowanii has been described for its biological N2-binding property as well as for its related species, PSB, as well as for producing IAA and siderophore, so it is likely that the K. cowanii strain we use has these capabilities. (Menendez et al. 2016, Brady et al 2013, Zhu et al. 2013, Lin 2012). In addition, extracellular polysaccharide (EPS) producing properties have been observed in E. ludwigii and K. cowanii strains under laboratory conditions, which are capable of improving soil structure. T. harzianum is known for its biocontrol and cellulose-degrading properties (Abdel-Fattah et al. 2007, Haddadin et al. 2009). Ph. Chrysosporium is the most well-known white-rot model organism and thus is a lignin-degrading organism, which, in combination with T. harzianum, may increase the rate of organic matter degradation (Haddadin et al. 2009).

However, in the third generation of agri-environmental applications of bacterial fertilizer, there are still unknown factors that need to be further investigated for their effectiveness (Bashan et al. 2013). bacterial 
fertilizer may behave differently and may not necessarily function on different soils (Kincses et al. 2008, Balláné et al. 2008). In order to eliminate this and to improve the functionality of the introduced living strains, natural clay minerals can be used to improve the primary Physico-chemical state of the soil, thereby creating a more favorable environment for both plants and microbes. They also help plants grow and gain nutrients with their mineral content (Solti 2000, Tállai 2011). Such a clay mineral is the alginite, which contains nearly 60 mineral elements. Its use is environmentally friendly and presents a low health risk to chemical methods (Kardos et al. 2011). With proper selection and selection of fertilizer strains, it is also possible to implement biotic and abiotic inoculations adapted to the given soil-environment conditions (Kovács et al. 2017).

In the present study, different soils were used to investigate the influence of the physico-chemical properties of soils on the effectiveness of the selected inoculants that favor plant growth.

\section{Materials and methods}

A pot experiment was set up in the light room of the Department of Soil Science and Water Management at Szent István University, Faculty of Horticulture. Under controlled conditions, light conditions were set for a $16 / 8$ hour day / night period for plant growth. The temperature was $22 \pm 2{ }^{\circ} \mathrm{C}$ and the relative humidity was $55 \pm 5 \%$. The pots were watered as required.

Soils: The plants were grown on five domestic soils with different characteristics. Their origins are shown in Figure 1. The soils have a neutral, slightly alkaline $\mathrm{pH}$, but they are different in binding and also in organic matter content. Soils correspond to the genetic soil types used in cultivation. The most important physicochemical properties of the soils used are shown in Table $1.850 \mathrm{~g}$ of dry soil was used per pot.

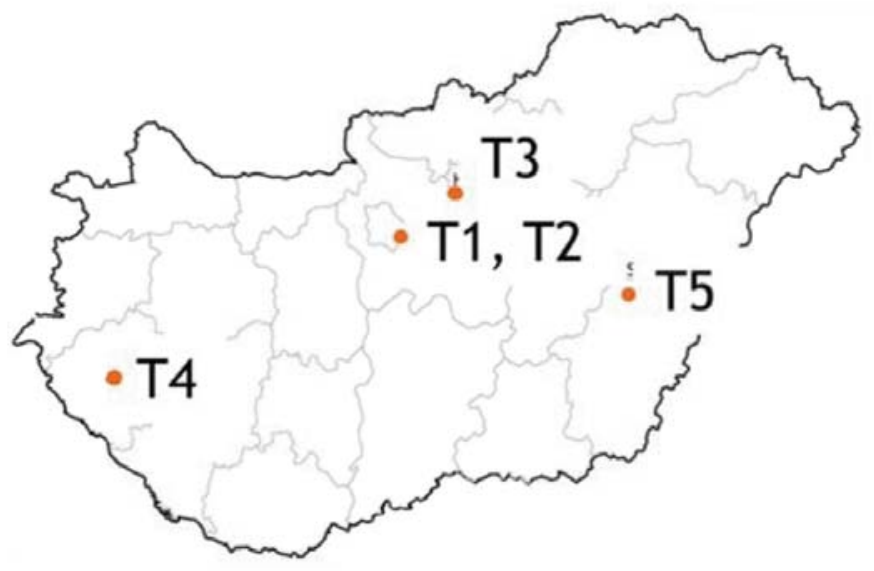

Figure 1. Types of soils used, and their origin are classified according to WRB (2015)

T1: Arenosols (Soroksár 1), T2: Gleysols (Soroksár 2), T3: Chernozems (Hatvan), T4: Luvisols (Tófej), T5: Gleysols (Szeghalom).

Bush beans (Phaseolus vulgaris var. Maxidor) were used as test plants. Plants were seeded in culture pots (4-4 seeds / pot) and after emergence the same number of plants (1 plant / pot) was left. The strains in the inoculation are listed in Table 2, along with their expected pre-laboratory-tested functions. One $\mathrm{ml}$ of inoculum was used per culture pots and in cotrol pots killed bacterial suspension was added. Soil samples were taken at $60 \%$ flowering at the same time as the experiment.

The number of colonies that can be cultivated on soils was determined by the MPN (Most Probable Number) method using the Hoskins table (Cochran 1949). Thus, the colonization numbers of all cultivable mesophilic aerobic bacteria, microscopic fungi and spore-forming bacteria were examined (Olsen 1996). enzymatic activity of the soil was determined by DHA (dehydrogenase) method (Veres et al. 2013). Even measured the height of the plant shoot, and shoot and root dry weight. 4-4 repetitions were used per treatment. 
Table 1. The main physicochemical properties of the used soils in the pot experiment.

\begin{tabular}{|l|c|c|c|c|c|}
\hline $\begin{array}{l}\text { Soils and investigated } \\
\text { properties }\end{array}$ & T1 & T2 & T3 & T4 & T5 \\
\hline Texture & Sand & Clay loam & Clay loam & Clay & Clay \\
\hline $\mathbf{p H}_{(\mathrm{H} 2 \mathrm{O})}$ & 7.49 & 7.42 & 7.44 & 7.50 & 7.61 \\
\hline $\mathbf{p H}$ & 6.94 & 7.13 & 6.58 & 6.74 & 6.45 \\
\hline $\begin{array}{l}\text { Water soluble salt } \\
\mathbf{m} / \mathbf{m} \%\end{array}$ & 0.0317 & 0.0216 & 0.02677 & 0.0555 & 0,0665 \\
\hline Amount of humus (H\%) & 2.18 & 4.09 & 4.63 & 3.89 & 3.75 \\
\hline
\end{tabular}

The results were processed using GraphPad Prism 6. The normality test was verified by the KolmogorovSmirnov test, the dispersion homogeneity by the Levene test. Statistical analysis of the results was performed by two-way analysis of variance (ANOVA) and Tukey's test, and the results were interpreted at $95 \%$ significance level $(\mathrm{p}<0.05)$.

Table 2. Potential and expected properties of soil strain microorganism strains

\begin{tabular}{|l|l|}
\hline Strain composition & Properties, abilities \\
\hline Enterobacter ludwigii & $\begin{array}{l}\text { PSB, Fusarium fungal antagonism, IAA-, siderophor and } \\
\text { extracellular polysaccharide production }\end{array}$ \\
\hline Bacillus subtilis & Cellulose decomposition, PSB, biocontrol \\
\hline Pseudomonas fluorescens & PSB, biocontrol effect, IAA- and siderophore production \\
\hline Kosakonia cowanii & Nitrogen bonding, PSB- and EPS production \\
\hline Trichorderma harziamum & Biocontrol effect, cellulose decomposition \\
\hline Phanerochaeta chrysosporium & Lignin degradation \\
\hline
\end{tabular}

Legend: PSB: phosphorus solubility, IAA: hormone production, EPS: polysaccharide production

\section{Results and discussion}

In the subsequent section of this article, all data refer to Table 3.

The greatest effect of the treatments on the measured parameters was on the cultivable germ count of microorganisms.

Inoculated $\mathrm{T} 5$ soil showed significantly higher values than all controls when examining the total number of cultivable mesophilic aerobic bacteria. Inoculated soil T1 and T4 showed higher values than the inoculated $\mathrm{T} 1$ and $\mathrm{T} 4$ soils. Thus, the bacterial components of the vaccine showed the most effective effect on the highest clay content soil.

In all cultivable microscopic fungal counts, the values of inoculated T4 and T5 soils were significantly higher compared to the controls. Among control soils, T4 was significantly higher compared to T1. It is not significant, but the tendency of the soils is higher than that of the treated soils, except for T2. This indicates that the fungal components, presumably primarily $T$. harzianum, successfully survived application and were able to persist in the soil until the time of measurement. The number of fungi also gave a similar result to the total number of bacteria, ie the treatment was more effective on the highest clay content soil.

The number of cultivable spore-forming bacteria was significantly higher than the inoculated T2 soil compared to the control, and in the control soils the T3 and T4 soils gave significantly higher values compared to the T2 soil. Similarly to the number of fungi, a nonsignificant but tendency-higher value is also observed for the inoculated soils.

This leads to the conclusion that the inoculum increased MPN values in all groups tested. T1 and T2 soils from Soroksar have lower MPN values, especially considering the number of microscopic fungi. This is 
HUNGARIAN AGRICULTURAL ENGINEERING

$N^{\circ} 37 / 2020$
SOIL MICROBIAL PARAMETERS AND SYNERGIES BETWEEN

BEAN GROWTH AND MICROBIAL INOCULUMS AS A DEPENDENCE OF FIVE SOILS WITH DIFFERENT CHARACTERISTICS

probably due to the looser soil structure. All bacteria and fungi showed the highest growth on the bound T4 and T5 soils, whereas the sporulated bacteria had a significant effect on the loose T2 soil. Such soils are subject to more extreme conditions in nature, since the looser the structure, the more easily the moisture is removed and the soils are also more exposed to heat fluctuations. This provided information on which soils of the inoculum components perform better.

Table 3. The studied parameters are soil (MPN) and plant. Data are shown as means $\pm \mathrm{SD}$.

Different small letter means there is significant difference between soils, and data written in bold type means there is significant difference between inoculated and control samples by

Tukey's multiple test $(\mathrm{P}<0.05), \mathrm{n}=4$.

\begin{tabular}{|c|c|c|c|c|c|c|}
\hline \multirow[b]{2}{*}{ Sample ID } & \multirow[b]{2}{*}{ Treatments } & \multicolumn{3}{|c|}{ MPN method } & \multicolumn{2}{|c|}{ Plant growth } \\
\hline & & $\begin{array}{c}\text { bacteria } \\
(\log C F U / g)\end{array}$ & $\begin{array}{l}\text { microscopi- } \\
\text { cal fungi } \\
(\log C F U / g)\end{array}$ & $\begin{array}{c}\text { spore-forming } \\
\text { bacteria } \\
(\log C F U / g)\end{array}$ & $\begin{array}{l}\text { dry weight } \\
\text { (g/plant) }\end{array}$ & $\begin{array}{l}\text { shoot length } \\
(\mathrm{cm})\end{array}$ \\
\hline \multirow{2}{*}{$\mathrm{T} 1$} & Control & $6.10 \pm 0.42^{\mathrm{a}}$ & $3.65 \pm 0.25^{b}$ & $5.45 \pm 0.22^{\mathrm{ab}}$ & $1.00 \pm 0.32^{b c}$ & $23.5 \pm 1.96^{\mathrm{ab}}$ \\
\hline & Inoculated & $5.90 \pm 0.35^{b}$ & $4.12 \pm 0.19^{b}$ & $5.75 \pm 0.43^{\mathrm{a}}$ & $0.94 \pm 0.38^{b c}$ & $21.0 \pm 1.14^{b}$ \\
\hline \multirow{2}{*}{$\mathrm{T} 2$} & Control & $5.97 \pm 0.47^{\mathrm{a}}$ & $3.84 \pm 0.41^{\mathrm{ab}}$ & $4.89 \pm 0.17^{b}$ & $0.82 \pm 0.37^{\mathrm{c}}$ & $21.4 \pm 1.92^{b}$ \\
\hline & Inoculated & $6.29 \pm 0.28^{\mathrm{ab}}$ & $3.40 \pm 0.31^{\mathrm{c}}$ & $5.54 \pm 0.35^{\mathrm{a}}$ & $0.62 \pm 0.02^{\mathrm{c}}$ & $24.0 \pm 3.90^{\mathrm{ab}}$ \\
\hline \multirow{2}{*}{ T3 } & Control & $6.29 \pm 0.28^{\mathrm{a}}$ & $4.43 \pm 0.14^{\mathrm{a}}$ & $5.63 \pm 0.52^{\mathrm{a}}$ & $1.87 \pm 0.44^{\mathrm{a}}$ & $27.1 \pm 2.84^{\mathrm{a}}$ \\
\hline & Inoculated & $5.94 \pm 0.23^{b}$ & $5.50 \pm 0.16^{\mathrm{a}}$ & $5.57 \pm 0.14^{\mathrm{a}}$ & $1.70 \pm 0.31^{\mathrm{a}}$ & $26.9 \pm 1.67^{\mathrm{a}}$ \\
\hline \multirow{2}{*}{$\mathrm{T} 4$} & Control & $6.08 \pm 0.55^{\mathrm{a}}$ & $4.12 \pm 0.34^{\mathrm{ab}}$ & $5.72 \pm 0.17^{\mathrm{a}}$ & $1.46 \pm 0.18^{\mathrm{ab}}$ & $24.4 \pm 0.74^{\mathrm{ab}}$ \\
\hline & Inoculated & $6.47 \pm 0.33^{\mathrm{ab}}$ & $4.50 \pm 0.16^{b}$ & $5.90 \pm 0.35^{\mathrm{a}}$ & $1.44 \pm 0.07^{\mathrm{ab}}$ & $23.8 \pm 1.62^{\mathrm{ab}}$ \\
\hline \multirow{2}{*}{ T5 } & Control & $6.09 \pm 0.32^{\mathrm{a}}$ & $4.23 \pm 0.57^{\mathrm{ab}}$ & $5.54 \pm 0.35^{\mathrm{ab}}$ & $1.41 \pm 0.29^{\mathrm{abc}}$ & $25.5 \pm 1.68^{\mathrm{ab}}$ \\
\hline & Inoculated & $6.80 \pm 0.19^{\mathrm{a}}$ & $5.33 \pm 0.27^{\mathrm{a}}$ & $5.73 \pm 0.29^{\mathrm{a}}$ & $1.13 \pm 0.41^{\mathrm{abc}}$ & $22.9 \pm 2.32^{\mathrm{ab}}$ \\
\hline
\end{tabular}

The impact of the microbial inoculants in the soil culturable bacteria count

Microbial soil inoculating has been shown to increase the biological status of soils. Thus, beneficial microorganisms can carry out their activities when they enter the soil..

\section{Changes in plant growth as a result of treatments}

Statistical analysis of the plant biomass weight showed that the dry weight of the shoot showed no significant difference between the control and the treated soils. In some soils, it was also observed that the dry weight of the inoculated plants was lower compared to the control plants. This tendency has been described previously (Jakab 2014), but relatively little attention is paid to such a negative effect on plant growth compared to expectations. The reason for this is the following effect. Microorganisms entered into the rhizosphere by inoculation should be fed to the root extrudates when plant photosynthetic activity is not yet sufficient and/or when there is not enough organic material in the soil for microbial nutrition. This may initially hold back the growth of the plants, as their photosynthetic product is thus not fully utilized for biomass growth. Further investigations will be needed to determine the actual factors involved.

Examine the shoot length, the inoculated plants did not show significant differences compared to control plants. Examining the soils, similar results were obtained as for the dry weight of the shoot, although the shoot length of the plants decreased in a trend-like manner.

\section{Assessment of differences between soils}

Significant differences were found between soils in the evaluation of many of the investigated attributions. Plants grown on T1 Soroksar soil were smaller compared to plants grown on T3 soil. In contrast, plants on T2 
soil were smaller than plants grown on T3 and T4 soil. This is due to the Physico-chemical properties of soils, which also affects the nutrient supply capacity of soils.

Examine the shoot length, the treatments did not show significant differences compared to untreated plants. Examining the soils, similar results were obtained as for the dry weight of the shoot, although the shoot length of the plants decreased in a trend-like manner.

We conclude that the initial physical condition of the soils has a major influence on the "susceptibility" of the soil to the effectiveness of the inoculation treatments (Kincses et al. 2008, Balláné et al. 2008). The high clay content of T5 soil provided more habitat for microorganisms, so the soil was generally more responsive to inoculation treatments than $\mathrm{T} 1$ soil. The more aerated soil with larger pore space primarily supported the growth of fungi in the inoculum (Trichorderma harzianum, Phanerochaeta chrysosporium) against the bacteria.

\section{Conclusions}

All in all, the effectiveness of inoculation is fundamentally influenced by the physical condition of the soil. On soil with higher clay content, MPN values increased as a result of treatments. This is most noticeable in the number of microscopic fungi, especially in T4 and T5 soils (Tófej, Szeghalom). This is likely to indicate the presence of $\mathrm{T}$. harzianum in the inoculum.

It is also possible to deduce from the dry weight of the plant shoots that there are significant differences in the basic Physico-chemical properties of the soils, which also influence the reactions to microbial inoculum treatments. In some soils, inoculations negatively influenced the growth of plants, which is explained by the very early inoculation relative to the stage of development of the plant. The influence of plant physiological properties and environmental conditions should be considered when choosing the time of inoculation.

\section{Acknowledgements}

This publication is created in number EFOP-3.6.1-16-2016-00016 The specialise of the SZIU Campus of Szarvas research and training profile with intelligent specialization in the themes of water management, hydroculture, precision mechanical engineering, alternative cropproduction. Supported by the ÚNKP-19-3-I New National Excellence Program of the Ministry for Innovation and Technology.

\section{References}

[1] Abdel-Fattah, G.M., Shabana, Y.M., Ismail, A.E., Rashad, Y.M. (2007) Trichoderma harzianum: a biocontrol agent against Bipolaris oryzae. Mycopathologia 164, 81-89.

[2] Ahmad, M., Adil, Z., Hussain, A., Mumtaz, M., Nafees, M., Ahmad, I., Jamil, M. (2019) Potential of phosphate solubilizing bacillus strains for improving growth and nutrient uptake in mungbean and maize crops. Pakistan Journal of Agricultural Sciences 56, 283-289.

[3] Balláné Kovács, A., Kremper, R., Vágó, I., Filep, T. (2008) Az NH4NO3 és a Phylazonit MC baktériumtrágya hatása a talaj könnyen oldható nitrogén-, foszfor-, és káliumtartalmára. Talajtani Vándorgyülés. 2008. május 28-29. 361-368.

[4] Bashan, Y., Kamnev, A.A, Luz, E. (2013) Tricalcium-phosphate is inappropriate as an universal selection factor for isoltaing and testing phosphate-solubilizing bacteria that enhance plant growth: a proposal for an alternative procedure. Biofertil. Soils. 49. 465-479.

[5] Brady C, Cleenwerck I, Venter S, Coutinho T, De Vos P. (2013) Taxonomic evaluation of the genus Enterobacter based on multilocus sequence analysis (MLSA): Proposal to reclassify E. nimipressuralis and E. amnigenus into Lelliottia gen. nov. as Lelliottia nimipressuralis comb. nov. and Lelliottia amnigena comb. nov., respectively, E. gergoviae and E. pyrinus into Pluralibacter gen. nov. as Pluralibacter gergoviae comb. nov. and Pluralibacter pyrinus comb. nov., respectively, E. cowanii, E. radicincitans, E. oryzae and E. arachidis into Kosakonia gen. nov. as Kosakonia cowanii comb. nov., Kosakonia radicincitans comb. nov., Kosakonia oryzae comb. nov. and Kosakonia arachidis comb. nov., respectively, and E. turicensis, E. helveticus and E. pulveris into Cronobacter as Cronobacter zurichensis nom. nov., Cronobacter helveticus 
comb. nov. and Cronobacter pulveris comb. nov., respectively, and emended description of the genera Enterobacter and Cronobacter. Syst Appl Microbiol; 36:309-319.

[6] Béni Á., Lajtha K., Kozma J., Fekete I. (2017) Application of a Stir Bar Sorptive Extraction sample preparation method with HPLC for soil fungal biomass determination in soils from a detrital manipulation study, Journal of Microbiological Methods 136:1-5.

[7] Cochran, W.G. (1949) Estimation of bacterial densities by means of the „Most Probable Number”. Biometrics 6 (2): 105-116.

[8] David, B.V., Chandrasehar, G., Selvam, P.N (2018) Pseudomonas fluorescens: A Plant-GrowthPromoting Rhizobacterium (PGPR) With Potential Role in Biocontrol of Pests of Crops. In: Crop Improvement Through Microbial Biotechnology. Elsevier, pp. 221-243.

[9] Dolkar, D., Dolkar, P., Angmo, S., Chaurasia, O. P., Stobdan, T. (2018) Stress tolerance and plant growth promotion potential of Enterobacter ludwigii PS1 isolated from Seabuckthorn rhizosphere. Biocatalysis and Agricultural Biotechnology, 14: 438-443.

[10] Dudás, A., Kotroczó, Zs., Vidéki, E., Wass-Matics, H., Kocsis, T., Szalai, Z., Végvári, Gy., Biró, B. (2017a) Fruit quality of tomato affected by single and combined bioeffectors in organically system. Pakistan Journal of Agricultural Sciences 54 (4): 847-856.

[11] Dudás, A., Szalai, Z.M., Vidéki, E., Wass-Matics, H., Kocsis, T., Végvári, Gy., Kotroczó, Zs., Biró, B. (2017b) Sporeforming bacillus bioeffectors for healthier fruit quality of tomato in pots and field. Applied Ecology And Environmental Research 15(4): 1399-1418.

[12] Fekete, I., Lajtha, K., Kotroczó, Zs., Várbíró, G., Varga, Cs., Tóth, J.A., Demeter, I., Veperdi, G., Berki, I. (2017) Long term effects of climate change on carbon storage and tree species composition in a dry deciduous forest. Global Change Biology 23 (8): 3154-3168.

[13] Haddadin, M.S.Y., Haddadin, J., Arabiyat, O.I., Hattar, B. (2009) Biological conversion of olive pomace into compost by using Trichoderma harzianum and Phanerochaete chrysosporium. Bioresource Technology 100, 4773-4782.

[14] Iuss Working Group Wrb. (2015). World reference base for soil resources 2014, update 2015: International soil classification system for naming soils and creating legends for soil maps. World Soil Resources Reports No. 106, 192.

[15] Jakab, A. (2014) Mütrágyák és biokészítmények hatása a talaj mikrobiológiai aktivitására és a termékenységére. PhD értekezés. Debreceni Egyetem. pp. 160.

[16] Kardos, L., Juhász, Á., Palkó, Gy., Oláh, J., Barkács, K., Záray, Gy. (2011) Enzyme activity analyses of anaerobic fermented sewage sludges. Applied Ecology and Environmental Research. 9(4): 333-339.

[17] Kim, Y.K., Lee, S.C., Cho, Y.Y., Oh, H.J., Ko, Y.H. (2012) Isolation of cellulolytic Bacillus subtilis strains from agricultural environments. ISRN Microbiology, pp. 1-9.

[18] Kincses, S., Filep, T., Kátai, J. (2008) Szerves-, mü-, és baktérium trágyázás hatása a talajok 0,01M CaCl2-oldható tápelem-tartalmára. Talajtani Vándorgyúlés. 2008. május 28-29. Nyíregyháza. p. 423-430.

[19] Kocsis, T., Biró, B. (2015) Bioszén hatása a talaj-növény-mikróba rendszerre: előnyök és aggályok. Agrokémia és Talajtan 64(1): 257-272.

[20] Kocsis, T., Biró, B., Kotroczó, Zs. (2018) Time-lapse effect of ancient plant coal biochar on some soil agrochemical parameters and soil characteristics. Environmental Science and Pollution Research 25(2): 990-999.

[21] Kotroczó Zs., Krakomperger Zs., Veres Zs., Vasenszki T., L. Halász J., Koncz G., Papp M., Tóth J. A. (2009) Talajlégzés vizsgálatok tartamhatású avarmanipulációs modellkísérletben. Természetvédelmi közlemények 15: 328-337.

[22] Kovács, R., Imre, Cs., Puspán, I., Rizó, B., Imri, Á., Pék, N., Kárpáti, É., Árvay, Gy., Romsics, Cs., Kutasi, J. (2017) Kedvezőtlen talajkémhatást és sóviszonyokat mutató, degradálódott talajokhoz alkalmazkodott stressztürő baktériumok szelektálása és törzsgyüjtemény létrehozása. Talajvédelem, (Okszerü talajhasználat - különszám), p. 85-96.

[23] Lin, L., Li, Z., Hu, C., Zhang, X., Chang, S., Yang, L., Li, Y., An, Q. (2012) Plant growth-promoting nitrogen-fixing Enterobacteriaceae in association with sugarcane plants growing in Guangxi, China. Microbes Environ; 27: 391-398. 
[24] Menéndez, E., Ramirez-Bahena, M.H., Peix, A., Tejedor, C., Mulas, R., González-Andrés, F., Martínez-Molina, E., Velázquez, E. (2016) Analysis of cultivable endophytic bacteria in roots of maize in a soil from León Province in Mainland Spain. In: González-Andrés, F., James, E. (Eds.), Biological Nitrogen Fixation and Beneficial Plant-Microbe Interaction. Springer International Publishing, Cham, pp. 45-53.

[25] Olsen, P.E, Sanda, E.S., Keyser, H.H., (1996) The enumeration and identification of Rhizobial bacteria in legume inoculant quality control procedures. NifTAL Center, USA, p. 96.

[26] Rajnish, P.S., Somesh, M., Prameela, J., Smita, R., Prabhat N.J., (2018) Effect of inoculation of zincresistant bacterium Enterobacter ludwigii CDP-14 on growth, biochemical parameters and zinc uptake in wheat (Triticum aestivum L.) plant. Ecological Engineering, 116: 163-173.

[27] Shoebitz, M., Ribaudo, C.M., Pardo, M.A., Cantore, M.L., Ciampi, L., Curá, J.A., (2009) Plant growth promoting properties of a strain of Enterobacter ludwigii isolated from Lolium perenne rhizosphere. Soil Biol. Biochem. 41:1768-1774.

[28] Solti, G., (2000) Talajjavítás és tápanyag-utánpótlása ökogazdálkodásban, Mezőgazda Kiadó. Budapest [29] Tállai, M., (2011) Bentonit and zeolite effecting biological activity of acidic sandy soils. PhD dissertation and Thesis, Debreceni Egyetem, Hankóczy J. Doctors School. pp. 110. (in Hungarian).

[30] Veres, Zs., Kotroczó, Zs., Magyaros, K., Tóth, J.A., Tóthmérész, B. (2013) Dehydrogenase activity in a litter manipulation experiment in temperate forest soil. Acta Silvatica Lign. Hungarica, 9: 25-33.

[31] Xiao-ying, G., Chun-e, H., Tao, L., Zhu, O. (2015) Effect of Bacillus subtilis and Pseudomonas fluorescens on Growth of Greenhouse Tomato and Rhizosphere Microbial Community. Journal of Northeast Agricultural University (English Edition) 22, 32-42.

[32] Zhu, B., Zhou, Q., Lin, L., Hu, C., Shen, P., Yang, L., An, Q., Xie, G., Li, Y. (2013), Enterobacter sacchari sp. nov., a nitrogen-fixing bacterium associated with sugar cane (Saccharum officinarum L.). Int. J. Syst. Evol. Microbiol.; 63:2577-2582. 